\title{
Leaching behaviour of lithium, cesium and rubidium from a clay sample of Kırka borate deposit in sulfuric acid solutions
}

\author{
Abdullah Obut ${ }^{1 *}$, İhan Ehsani², Zeynep Aktosun ${ }^{3}$, Abdulkerim Yörükoğlư ${ }^{4}$ İsmail Girgin ${ }^{5}$, Abidin Temel $^{6}$, \\ Hacı Deveci ${ }^{7}$ \\ ${ }^{1}$ Hacettepe University, Mining Engineering Department, 06800, Ankara, Turkey, ORCID ID orcid.org/0000-0003-2979-322X \\ ${ }^{2}$ Hacettepe University, Mining Engineering Department, 06800, Ankara, Turkey, ORCID ID orcid.org/0000-0001-9741-8777 \\ ${ }^{3}$ Boron Research Institute, 06530, Ankara, Turkey, ORCID ID orcid.org/0000-0001-9019-0183 \\ ${ }^{4}$ Boron Research Institute, 06530, Ankara, Turkey, ORCID ID orcid.org/0000-0003-3194-3901 \\ ${ }^{5}$ Boron Research Institute, 06530, Ankara, Turkey, ORCID ID orcid.org/0000-0002-7611-9070 \\ ${ }^{6}$ Hacettepe University, Geological Engineering Department, 06800, Ankara, Turkey, ORCID ID orcid.org/0000-0002-8051-4065 \\ ${ }^{7}$ Karadeniz Technical University, Mining Engineering Department, 61080, Trabzon, Turkey, ORCID ID orcid.org/0000-0003-4105-0912
}

\section{ARTICLE INFO}

Article history:

Received June 24, 2020

Accepted October 30, 2020

Available online December 29, 2020

Research Article

DOI: $10.30728 /$ boron. 757308

Keywords:

Cesium,

Kırka borate deposit,

Lithium,

Rubidium,

Sulfuric acid leaching

\begin{abstract}
In this study, the leaching behaviour of lithium, together with cesium and rubidium, from a clay sample of Kırka borate deposit in sulfuric acid solutions was investigated with chemical, XRD, FTIR, DTA analyses methods and specific surface area measurements. It was observed that the leaching behaviours of lithium, cesium and rubidium were quite similar in character in that their extent of leaching tended to improve with increasing sulfuric acid concentration, especially in the range of 0.1 to $2 \mathrm{~mol} \cdot \mathrm{dm}^{-3}$, at the highest leaching temperature of $363 \mathrm{~K}$. Further increase of the acid concentration to $4 \mathrm{~mol} \cdot \mathrm{dm}^{-3} \mathrm{H}_{2} \mathrm{SO}_{4}$ appeared to have a limited improvement in their extent of leaching. Under the optimum conditions, $2 \mathrm{~mol} \cdot \mathrm{dm}^{-3} \mathrm{H}_{2} \mathrm{SO}_{4}$ concentration and $363 \mathrm{~K}$ leaching temperature, the leaching ratios reached for lithium ( $\mathrm{Li}$ ), cesium (Cs) and rubidium $(\mathrm{Rb})$ were $97.2 \%, 83.7 \%$ and $65.2 \%$, respectively. The results of XRD, FTIR and DTA analyses applied to the clay sample and the leaching residue obtained after leaching of the clay sample under the optimum conditions collectively showed that almost complete destruction of crystalline smectite structure(s) in the clay sample caused by acid leaching resulted in the formation of amorphous silica phase in the leaching residue. During this transformation, as expected, the specific surface area of the clay sample increased, from 59 to $406 \mathrm{~m}^{2} / \mathrm{g}$. The results obtained in this preliminary study may be exploited for the treatment of very high tonnages of clay containing processing waste of Kırka boron plant as potential Li (Cs and/or $\mathrm{Rb})$ resource.
\end{abstract}

\section{Introduction}

Lithium ( $\mathrm{Li})$, as the lowest density metal $\left(0.534 \mathrm{~g} / \mathrm{cm}^{3}\right)$, is the $25^{\text {th }}$ most abundant $(20 \mathrm{mg} / \mathrm{kg})$ element in the earth's crust and does not occur free in nature. It is used extensively in batteries, glasses and ceramics, lubricants, and also used in metallurgical and nuclear industries. Recently, the academic and industrial interest in Li has significantly increased because of the ever-increasing demand for electric/hybrid vehicles, power storage systems and smart devices (phones, tablets, computers) that use rechargeable Li-ion batteries, which have unique high specific energy densities $(100-265 \mathrm{~W} \cdot \mathrm{h} / \mathrm{kg})$ and life span cycles (400-1200). On the other hand, primary Li production is mostly done from two natural sources, e.g. pegmatite deposits and salt-lake brines, and therefore, diversification of Li resources is particularly important for meeting the increasing demand for Li in the battery industry around the world [1-8].

Although economically no exploitable Li resources are present in Turkey, there are some lakes (up to 325 $\left.\mathrm{mg} \cdot \mathrm{dm}^{-3} \mathrm{Li}\right)$ and clays $\left(0.17-0.58 \% \mathrm{Li}_{2} \mathrm{O}\right.$, in different borate deposits) containing noticeable amounts of $\mathrm{Li}$ [9]. There appear a few studies on the leaching of $\mathrm{Li}$ from the clays of the Kırka borate deposit in acid solutions. Mordoğan et al. [10] investigated the leaching of $\mathrm{Li}$ from the ulexite zone clay sample (with $0.56 \%$ $\mathrm{Li}_{2} \mathrm{O}$ ) of the Kırka borate deposit containing dolomite, montmorillonite and hectorite in sulfuric acid (up to about $3.26 \mathrm{~mol} \cdot \mathrm{dm}^{-3} \mathrm{H}_{2} \mathrm{SO}_{4}$ ) solutions. They found that the leaching of $\mathrm{Li}$ improved with increasing the acid concentration and the Li leaching ratio of about $92 \%$ was achieved at an acid concentration of approximately $1.63 \mathrm{~mol} \cdot \mathrm{dm}^{-3} \mathrm{H}_{2} \mathrm{SO}_{4}$. They also demonstrated 
the beneficial effect of increasing the temperature from $293 \mathrm{~K}$ to $353 \mathrm{~K}$ on the rate and extent of leaching of $\mathrm{Li}$, i.e. leaching ratio of over $90 \%$ Li was reached at 353 $\mathrm{K}$ compared with about $65 \%$ at $293 \mathrm{~K}$ within the same period of leaching time ( 0.5 hour). These investigators also noted that acid leaching was not particularly selective for Li dissolution (99\%) with a substantial dissolution of iron (42.97\%), magnesium (58.10\%) and calcium (35.04\%) under the optimum conditions of leaching. On the other hand, Lee et al. [11] reported a leaching ratio of $89 \%$ for Li from a smectitic clay sample (having $0.39 \% \mathrm{Li}_{2} \mathrm{O}$ ) of the Kırka borate deposit in $0.25 \mathrm{~mol} \cdot \mathrm{dm}^{-3}$ hydrochloric acid solution for 10 hours of leaching time. Earlier studies $[10,11]$ appear to focus essentially on the leaching of Li and the other components such as cesium (Cs) and rubidium ( $\mathrm{Rb}$ ) mostly being overlooked. In this regard, Baydır and Erdoğan [12] studied the extraction of $\mathrm{Rb}$ from the montmorillonite waste sample (containing $>1000 \mu \mathrm{g} / \mathrm{g} \mathrm{Rb}$ ) of the Kırka deposit in hydrochloric and nitric acid solutions and they observed that $\mathrm{Rb}$ could not be leached to the desirable extent in solutions of up to $1 \mathrm{~mol} \cdot \mathrm{dm}^{-3} \mathrm{HCl}$ or $\mathrm{HNO}_{3}$ concentration.

In this study, the leaching behaviour of $\mathrm{Li}$, together with $\mathrm{Cs}$ and $\mathrm{Rb}$, from a clay sample $\left(1.28 \% \mathrm{Li}_{2} \mathrm{O}\right)$ of the Kırka borate deposit in aqueous $\mathrm{H}_{2} \mathrm{SO}_{4}$ solutions was investigated in order to collect new data for possible hydrometallurgical processing of clay containing processing waste of the Kırka boron plant. The handpicked clay sample from the Kırka borate deposit was used to determine the leaching behaviour of Li as well as $\mathrm{Cs}$ and $\mathrm{Rb}$ from the clay sample in sulfuric acid solutions. Furthermore, the characterization of the sample, as well as the leaching residue, was carried out to provide an insight into the leaching peculiarities of the clay sample.

\section{Materials and methods}

A light-green coloured clay sample taken from the Kırka borate deposit (Eskisehir, Turkey) was used in the leaching experiments after grinding in a mortar. The particle size distribution (Malvern Mastersizer 3000 ) of the ground sample showed that $80 \%$ and $100 \%$ passing sizes of the sample were $17 \mu \mathrm{m}$ and 76 $\mu \mathrm{m}$, respectively (Figure 1). The chemical composition of the ground sample, determined by XRF analysis (AcmeLabs, Bureau Veritas), was given in Table 1. In addition, Cs and Rb (by Perkin Elmer ELAN 9000 ICPMS) contents of the sample were also determined as 544 and $179 \mathrm{mg} / \mathrm{kg}$, respectively.

The XRD (Panalytical Empyrean, CuKa radiation, measured after equilibrating with room atmosphere) patterns of the whole-rock (Figure 2) and the clay fractions (Figure 3) of the sample, which were prepared according to Gündoğdu and Yılmaz [13], have indicated that the sample is composed predominantly of smectite group clay mineral(s) and contained feldspar as the impurity. The very small intensity peak at about $1.00 \mathrm{~nm}$, observed especially in the XRD patterns of air-dried and glycolated clay fractions, may be an indication of the presence of different clay mineral(s) in the studied sample.

A representative leaching experiment was started by the addition of a calculated amount of clay sample into a $250 \mathrm{~cm}^{3}$ Pyrex reactor containing aqueous sulfuric acid solution at the pre-determined concentration and the temperature. The leaching experiment continued for one hour under constant speed magnetic stirring to keep all solid particles in suspension. The leaching

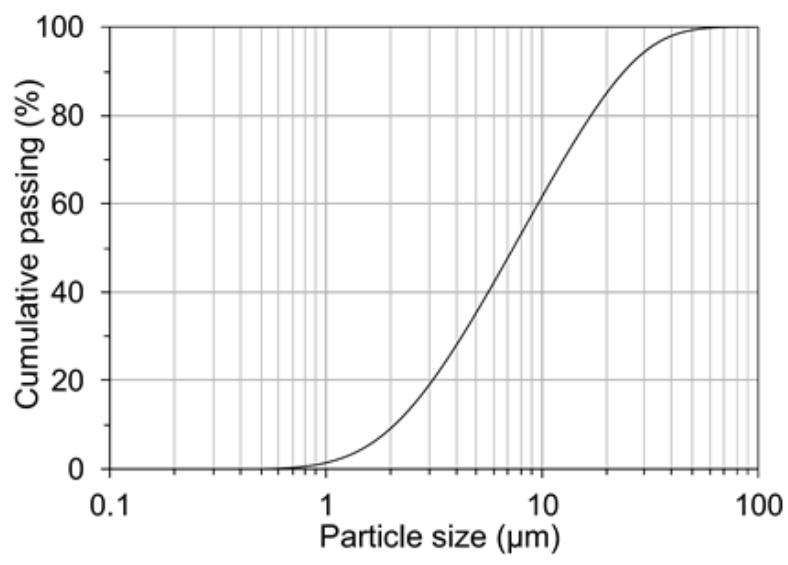

Figure 1. The particle size distribution of the sample.

Table 1. The chemical composition (wt.-\%) of the sample.

\begin{tabular}{|c|c|c|c|}
\hline Component & $\begin{array}{c}\text { Chemical } \\
\text { Composition } \\
\text { (wt.-\%) }\end{array}$ & Component & $\begin{array}{c}\text { Chemical } \\
\text { Composition } \\
\text { (wt.-\%) }\end{array}$ \\
\hline $\mathrm{SiO}_{2}$ & 60.58 & SrO & 0.59 \\
\hline $\mathrm{Al}_{2} \mathrm{O}_{3}$ & 14.91 & $\mathrm{Na}_{2} \mathrm{O}$ & 0.49 \\
\hline MgO & 7.82 & $\mathrm{~B}_{2} \mathrm{O}_{3}$ a) & 0.35 \\
\hline $\mathrm{K}_{2} \mathrm{O}$ & 2.73 & $\mathrm{TiO}_{2}$ & 0.16 \\
\hline $\mathrm{Fe}_{2} \mathrm{O}_{3}$ & 2.50 & $\mathrm{P}_{2} \mathrm{O}_{5}$ & 0.02 \\
\hline $\mathrm{Li}_{2} \mathrm{O}$ a) & 1.28 & MnO & 0.01 \\
\hline $\mathrm{CaO}$ & 1.25 & L.O.I. b) & 7.50 \\
\hline
\end{tabular}

a) by Thermo Scientific iCAP 7000 ICP-OES b) Loss on ignition

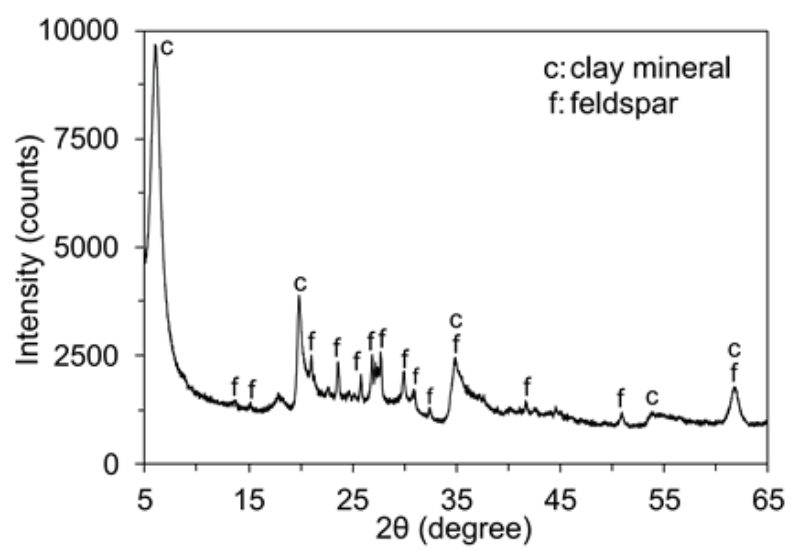

Figure 2. The whole-rock XRD pattern of the sample. 


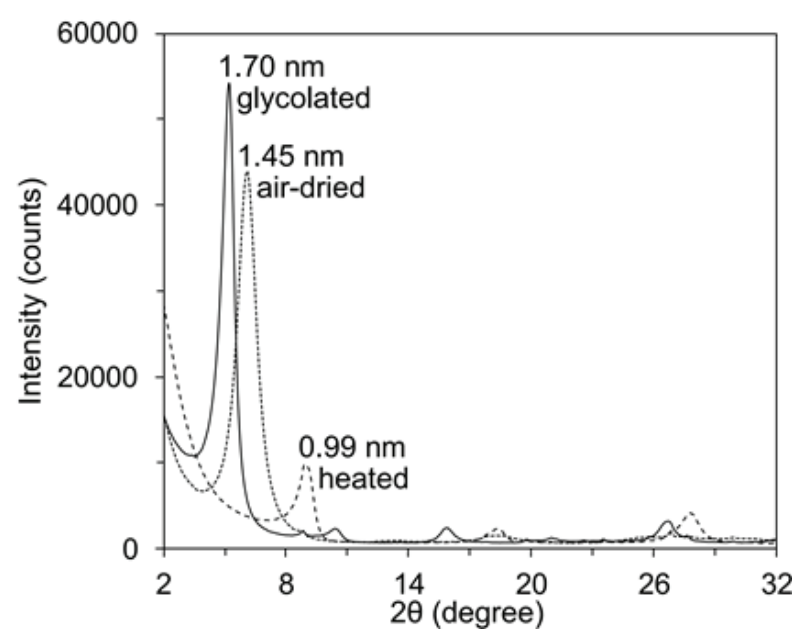

Figure 3. The XRD patterns of clay fractions of the sample.

conditions, i.e. acid concentration $(0.1,1,2$ and 4 $\left.\mathrm{mol} \cdot \mathrm{dm}^{-3} \mathrm{H}_{2} \mathrm{SO}_{4}\right)$, temperature $(298,323$ and $363 \mathrm{~K})$, leaching time $(1 \mathrm{~h})$ and solid/liquid ratio $\left(1 \mathrm{~g} / 10 \mathrm{~cm}^{3}\right)$, were selected according to the findings in preliminary tests and previous studies in the literature $[10,14,15]$. After the completion of a leaching experiment, the solid leaching residue was separated from the loaded leaching solution, which was analyzed for $\mathrm{Li}, \mathrm{Rb}$ and $\mathrm{Cs}$ to reveal the leaching behaviours of these metals from the studied clay sample. In addition, the XRD patterns (Panalytical Empyrean, CuKa radiation, measured after equilibrating with room atmosphere), the B.E.T. specific surface areas (Quantachrome Autosorb-1, by nitrogen adsorption following degassing for 2 hours at $378 \mathrm{~K}$ ), the FT-IR spectra (Varian 660-IR, KBr pellet method) and the DTA curves (Setaram Labsys, under static air atmosphere at a heating rate of $0.167 \mathrm{~K} / \mathrm{s}$, measured after equilibrating with room atmosphere) of the clay sample and the leaching residue were also determined to provide an insight into the leaching behaviour of the clay sample in sulfuric acid solutions.

\section{Results and discussion}

The effects of sulfuric acid concentration on the leaching ratios of $\mathrm{Li}, \mathrm{Cs}$ and $\mathrm{Rb}$ were given in Figures 4 to 6 , respectively. As shown in Figures 4 to 6 , the lowest leaching ratios of these metals were obtained at the lowest leaching temperature tested $(298 \mathrm{~K})$. Increasing the temperature from $298 \mathrm{~K}$ to $323 \mathrm{~K}$ improved their leaching from the sample and the highest leaching ratios were obtained at the highest leaching temperature of $363 \mathrm{~K}$. The leaching ratio of $\mathrm{Li}$, which is probably present in crystal structure of the smectite component of the sample according to Mordoğan et al. [10] and Lee et al. [11], increased substantially from 3.4 to $97.2 \%$ with increasing acid concentration from 0.1 to $2 \mathrm{~mol} \cdot \mathrm{dm}^{-3} \mathrm{H}_{2} \mathrm{SO}_{4}$ at $363 \mathrm{~K}$. Almost complete leaching of $\mathrm{Li}(99.7 \%)$ from the clay sample was achieved in 4 $\mathrm{mol} \cdot \mathrm{dm}^{-3} \mathrm{H}_{2} \mathrm{SO}_{4}$ solution at $363 \mathrm{~K}$. A similar leaching behaviour in character with positive influence of increasing acid concentration was also observed for Cs and $\mathrm{Rb}$ at $363 \mathrm{~K}$. The leaching ratios of $\mathrm{Cs}$ and $\mathrm{Rb}$ varied from $83.7 \%$ for $\mathrm{Cs}$ and $65.2 \%$ for $\mathrm{Rb}$ in $2 \mathrm{~mol} \cdot \mathrm{dm}^{-3}$ $\mathrm{H}_{2} \mathrm{SO}_{4}$ solution to $92.4 \%$ for $\mathrm{Cs}$ and $68.9 \%$ for $\mathrm{Rb}$ in 4 $\mathrm{mol} \cdot \mathrm{dm}^{-3} \mathrm{H}_{2} \mathrm{SO}_{4}$ solution at $363 \mathrm{~K}$. Based on these leaching data, $2 \mathrm{~mol} \cdot \mathrm{dm}^{-3} \mathrm{H}_{2} \mathrm{SO}_{4}$ concentration and 363 $\mathrm{K}$ leaching temperature were selected as the optimum conditions for dissolution of these metals from the clay sample.

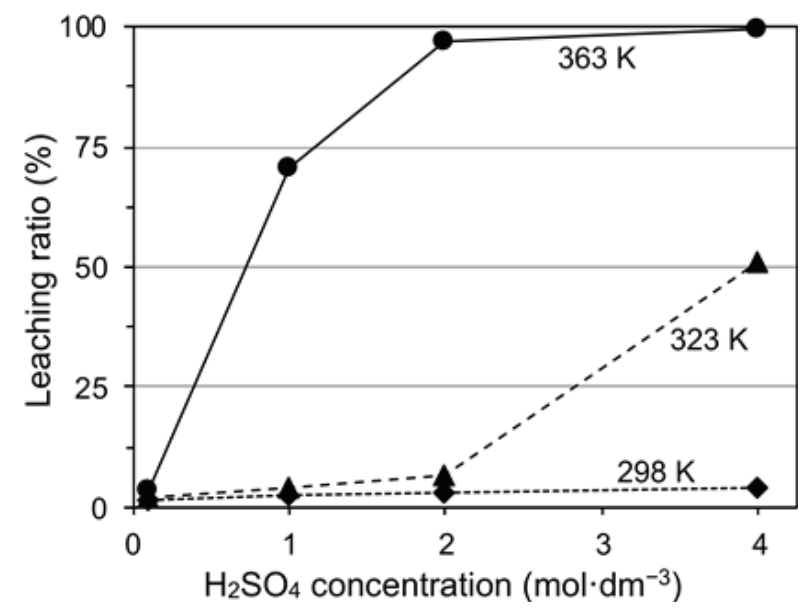

Figure 4. The effects of sulfuric acid concentration on the leaching of lithium.

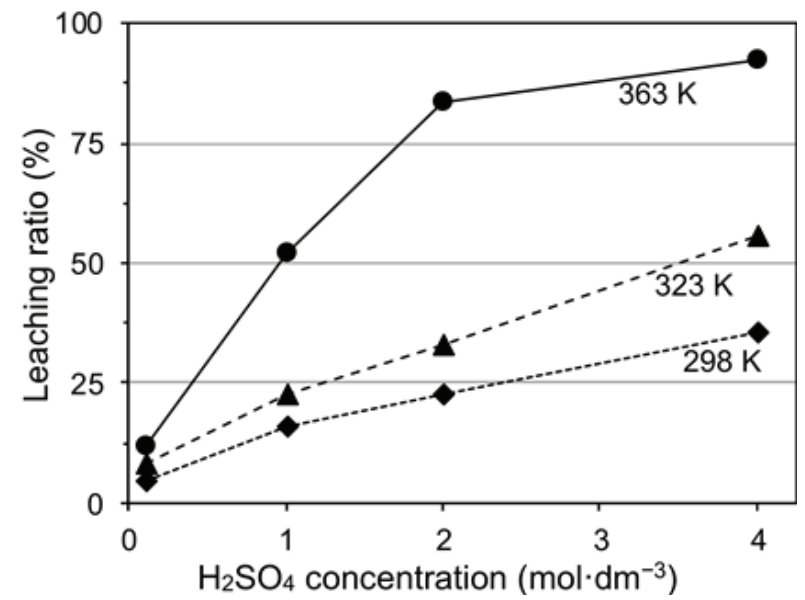

Figure 5. The effects of sulfuric acid concentration on the leaching of cesium.

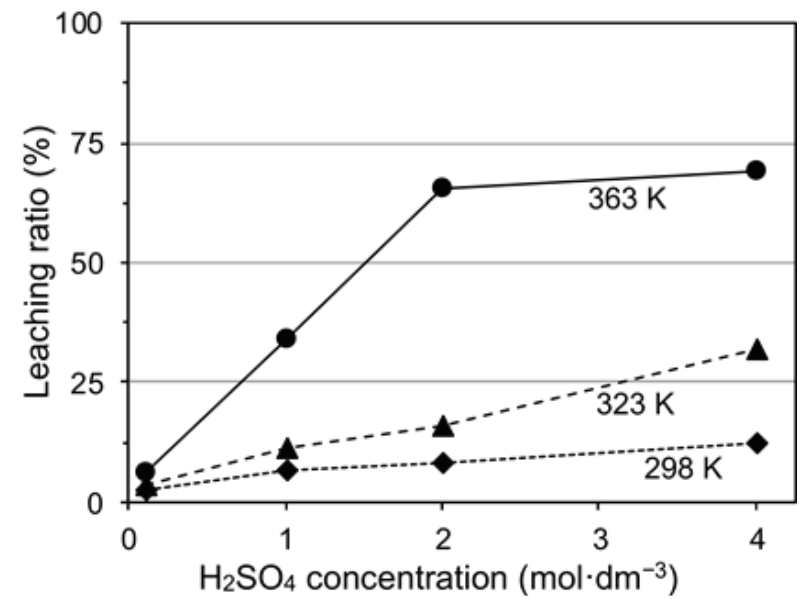

Figure 6. The effects of sulfuric acid concentration on the leaching of rubidium. 
There are only a few literature studies on the acid leaching of Li from different clay samples of the Kırka borate deposit. In this respect, Mordoğan et al. [10] obtained a Li leaching ratio of $99 \%$ from a $-500 \mu \mathrm{m}$ Kırka ulexite zone clay sample containing approximately $0.56 \% \mathrm{Li}_{2} \mathrm{O}$ in $\sim 1.63 \mathrm{~mol} \cdot \mathrm{dm}^{-3} \mathrm{H}_{2} \mathrm{SO}_{4}$ solution within 2 hours at $353 \mathrm{~K}$. Lee et al. [11] reported $89 \%$ dissolution of $\mathrm{Li}$ from a $-74 \mu \mathrm{m}$ clay sample of the Kırka deposit with approximately $0.39 \% \mathrm{Li}_{2} \mathrm{O}$ content after leaching in $0.25 \mathrm{~mol} \cdot \mathrm{dm}^{-3} \mathrm{HCl}$ solution for 10 hours at solid/liquid ratio of $1 \mathrm{~g} / 200 \mathrm{~cm}^{3}$. In addition, Baydır and Erdoğan [12] observed that Rb could not be leached to the desirable extent in water or acid solutions $(0.1$ to $1 \mathrm{~mol} \cdot \mathrm{dm}^{-3} \mathrm{HCl}$ and 0.1 to $1 \mathrm{~mol} \cdot \mathrm{dm}^{-3} \mathrm{HNO}_{3}$ ) from 'montmorillonite waste' sample of the Kırka deposit, which was identified to be potassium feldspar containing 1148-1690 $\mu \mathrm{g} / \mathrm{g} \mathrm{Rb}$.

On the other hand, Mordoğan et al. [10] and Helvaci et al. [9] stated that most of Kırka smectites occur as hectorite. In the literature, sulfuric acid leaching of hectorite samples appears to have received limited interest. Komadel et al. [14] reported a $50 \%$ extraction of $\mathrm{Li}$ from a hectorite sample having approximately $1.09 \% \mathrm{Li}_{2} \mathrm{O}$ (solid/liquid ratio: $1 \mathrm{~g} / 200 \mathrm{~cm}^{3}$ ) in $1 \mathrm{~mol} \cdot \mathrm{dm}^{-3} \mathrm{H}_{2} \mathrm{SO}_{4}$ at $293 \mathrm{~K}$ for 2.7 hours. However, they reported complete extraction of Li when the leaching time was extended to 8 hours under the same conditions. van Rompaey et al. [16] indicated the influence of leaching time on the dissolution of $\mathrm{Li}$ from a hectorite sample $\left(0.94 \% \mathrm{Li}_{2} \mathrm{O}\right)$. These researchers noted that the leaching of $\mathrm{Li}$ increased from 25 to $70 \%$ with extending the leaching time from 2.25 to 6 hours under the conditions of $1 \mathrm{~g} / 200$ $\mathrm{cm}^{3}$ solid/liquid ratio, $2 \mathrm{~mol} \cdot \mathrm{dm}^{-3} \mathrm{H}_{2} \mathrm{SO}_{4}$ concentration and $293 \mathrm{~K}$ temperature.

The XRD pattern of the leaching residue obtained after leaching under optimum conditions (in $2 \mathrm{~mol} \cdot \mathrm{dm}^{-3}$ $\mathrm{H}_{2} \mathrm{SO}_{4}$ at $363 \mathrm{~K}$ ) was given in Figure 7. The disappearance of basal smectite peak at $2 \theta$ value of $\sim 6.03^{\circ}$ (see Figure 2 ) and the newly formed hump-type peak centered between $2 \theta\left({ }^{\circ}\right)=22-23$ indicated near-total dissolution of the main smectite component of the sample leaving an amorphous silica phase in the residue. On the other hand, the XRD peaks belonging to feldspar in the sample were still present in the pattern of leaching residue, indicating its higher resistance to sulfuric acid leaching. The very small intensity peak observed in the XRD pattern of the leaching residue at a $2 \theta$ value of approximately $19.9^{\circ}$ may be an indication of the presence of trace amounts of undissolved smectite phase. The results of XRD analyses and the extensive metal leaching ratios obtained in $2 \mathrm{~mol} \cdot \mathrm{dm}^{-3} \mathrm{H}_{2} \mathrm{SO}_{4}$ at $363 \mathrm{~K}$ for $\mathrm{Li}(97.2 \%)$ and $\mathrm{Cs}(83.7 \%)$ may suggest that these two metals probably associated with the clay mineral(s) in the sample. On the other hand, a comparatively lower leaching ratio of $\mathrm{Rb}(65.2 \%)$ may suggest that $\mathrm{Rb}$ probably related to the feldspar phase in the sample [12, www.mindat.org]. Further detailed

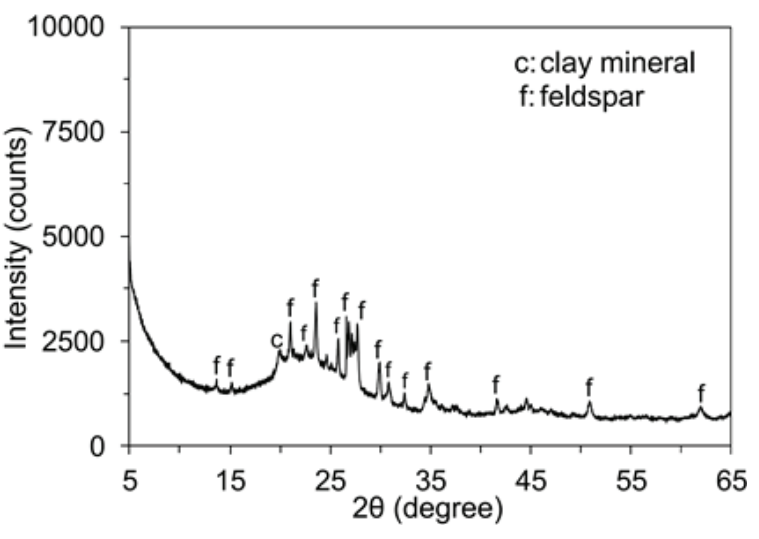

Figure 7. The XRD pattern of the leaching residue.

investigations are apparently needed to find out the exact source(s) of these metals in the studied clay sample.

The formation of amorphous silica phase following acid leaching of smectites, especially hectorites, also appeared to be observed in other studies. Madejová et al. [17] reported a complete conversion of a hectorite sample to an amorphous silica phase after leaching for $1 \mathrm{~h}$ in a $0.5 \mathrm{~mol} \cdot \mathrm{dm}^{-3} \mathrm{HCl}$ solution at $293 \mathrm{~K}$. Steudel et al. [15] also obtained amorphous silica in the leaching residue formed after leaching of a clay sample containing $93.9 \%$ hectorite, $3.1 \%$ calcite, $2.1 \%$ analcime and $0.7 \%$ ankerite in $5 \mathrm{~mol} \cdot \mathrm{dm}^{-3} \mathrm{H}_{2} \mathrm{SO}_{4}$ for $1.5 \mathrm{~h}$ at $353 \mathrm{~K}$ (solid/liquid ratio: $1 \mathrm{~g} / 100 \mathrm{~cm}^{3}$ ).

The leaching of the clay sample in $2 \mathrm{~mol} \cdot \mathrm{dm}^{-3} \mathrm{H}_{2} \mathrm{SO}_{4}$ at $363 \mathrm{~K}$ for $1 \mathrm{~h}$ appeared to lead to a significant increase in the B.E.T. specific surface area of the sample from 59 to $406 \mathrm{~m}^{2} / \mathrm{g}$. This increase is probably due to the transformation of the main crystalline smectite component of the sample to an amorphous silica phase. Such an increase in the surface area of smectites following acid leaching was also observed by Steudel et al. [15]. They reported that the specific surface area of a hectorite sample increased from 48 to $280 \mathrm{~m}^{2} / \mathrm{g}$ after leaching for $1.5 \mathrm{~h}$ in $5 \mathrm{~mol} \cdot \mathrm{dm}^{-3} \mathrm{H}_{2} \mathrm{SO}_{4}$ at $353 \mathrm{~K}$.

In addition to the findings in the XRD and B.E.T. analyses, the formation of a hydrous amorphous silica phase could also be substantiated using FTIR analyses. The FTIR spectrum (Figure 8a) of the residue obtained after leaching under the optimum conditions showed absorptions at $796 \mathrm{~cm}^{-1}$, a shoulder between at 970 $980 \mathrm{~cm}^{-1}$, at $1086 \mathrm{~cm}^{-1}$, a shoulder near $1200 \mathrm{~cm}^{-1}$, at $1635 \mathrm{~cm}^{-1}$ and $3440 \mathrm{~cm}^{-1}$, all belong to water and silicon-oxygen bonds in hydrous amorphous silica phases, as indicated in the literature $[14,15,17]$.

The DTA curves of the sample and the residue (obtained under the leaching conditions of $2 \mathrm{~mol} \cdot \mathrm{dm}^{-3}$ $\mathrm{H}_{2} \mathrm{SO}_{4}, 363 \mathrm{~K}$ and $1 \mathrm{~h}$ ) were presented in Figure 8b. The DTA curve of the sample showed a large endothermic dehydration peak at $403 \mathrm{~K}$ with a shoulder at $467 \mathrm{~K}$ and small intensity high-temperature dehy- 

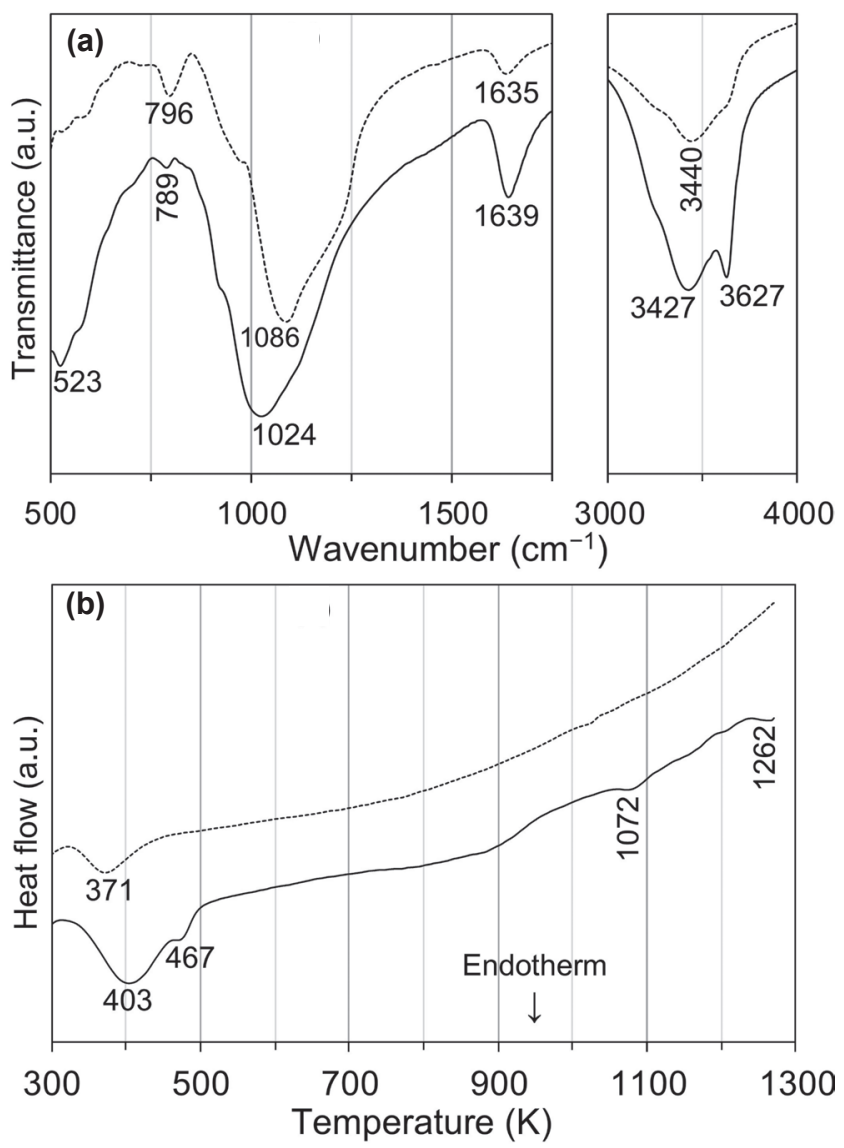

Figure 8. The FTIR spectra (a) and the DTA curves (b) of the sample (full lines) and the leaching residue (dotted lines).

droxylation (and probable recrystallization or new phase formation) peaks above $873 \mathrm{~K}$, both are characteristic for smectites $[18,19]$. The destruction of the smectite phase in the sample and the formation of the hydrous amorphous phase in the leaching residue could be observed by the disappearance of dehydration and high-temperature peaks in the DTA curve of the leaching residue [20]. Futhermore, the appearance of a single endothermic dehydration peak with no visible distinct high-temperature peak(s) in the DTA curve is also an indication of the presence of a hydrous amorphous phase in the residue [21].

\section{Conclusions}

In this work, the leaching behaviours of $\mathrm{Li}, \mathrm{Cs}$ and $\mathrm{Rb}$ from a clay sample taken from the Kırka borate deposit in sulfuric acid solutions were investigated. Various characterization methods were applied to the clay sample and the leaching residue. A similar trend for leaching of $\mathrm{Li}, \mathrm{Cs}$ and $\mathrm{Rb}$ was observed at the highest leaching temperature of $363 \mathrm{~K}$ in response to the increase in sulfuric acid concentration. The lowest leaching ratios of these elements were found to occur in all acid concentrations tested at $298 \mathrm{~K}$. Increasing the temperature from $298 \mathrm{~K}$ to $363 \mathrm{~K}$ had a profound effect on the leaching of $\mathrm{Li}, \mathrm{Cs}$ and $\mathrm{Rb}$. Under the optimum conditions (i.e. $2 \mathrm{~mol} \cdot \mathrm{dm}^{-3} \mathrm{H}_{2} \mathrm{SO}_{4}$ and $363 \mathrm{~K}$ ), the leac- hing ratio values obtained for $\mathrm{Li}, \mathrm{Cs}$ and $\mathrm{Rb}$ were 97.2, 83.7 and $65.2 \%$, respectively. The XRD, FTIR and DTA analyses indicated that in the acid leaching under optimum conditions, the crystalline smectite structure(s) in the clay sample was destructed and a hydrous amorphous silica phase was formed, with a concomitant increase in the specific surface area (from 59 to 406 $\mathrm{m}^{2} / \mathrm{g}$ ). The findings of this preliminary study may be exploited in the further hydrometallurgical processing of the vast amount of clay containing processing waste that has been generated and already accumulated over the years in the Kırka boron plant.

\section{Acknowledgements}

This study was supported by Boron Research Institute (BOREN, Project no: 2019-30-06-30-005).

\section{References}

[1] Vikström H., Davidsson S., Höök M., Lithium availability and future production outlooks, Appl. Energy, 110, 252-266, 2013

[2] Meshram P., Pandey B. D., Mankhand T. R., Extraction of lithium from primary and secondary sources by pretreatment, leaching and separation: A comprehensive review, Hydrometallurgy, 150, 192-208, 2014.

[3] Choubey P. K., Kim M. S., Srivastava R. R., Lee J. C., Lee J. Y., Advance review on the exploitation of the prominent energy-storage element: Lithium. Part I: From mineral and brine resources, Miner. Eng., 89, 119-137, 2016.

[4] Swain B., Recovery and recycling of lithium: A review, Sep. Purif. Technol., 172, 388-403, 2017.

[5] Li H., Eksteen J., Kuang G., Recovery of lithium from mineral resources: State-of-the-art and perspectivesA review, Hydrometallurgy, 189, 105129, 2019.

[6] Tadesse B., Makuei F., Albijanic B., Dyer L., The beneficiation of lithium minerals from hard rock ores: $A$ review, Miner. Eng., 131, 170-184, 2019.

[7] Gu H., Guo T., Wen H., Luo C., Cui Y., Du S., Wang N., Leaching efficiency of sulfuric acid on selective lithium leachability from bauxitic claystone, Miner. Eng., 145, 106076, 2020.

[8] Karrech A., Azadi M. R., Elchalakani M., Shahin M. A., Seibi A. C., A review on methods for liberating lithium from pegmatites, Miner. Eng., 145, 106085, 2020.

[9] Helvaci C., Mordogan H., Çolak M., Gündogan I., Presence and distribution of lithium in borate deposits and some recent lake waters of west-central Turkey, Int. Geol. Rev., 46, 177-190, 2004 (in Turkish).

[10] Mordoğan H., Akdağ M., Helvacı C., Lithium recover from low-grade lithium-bearing clays by $\mathrm{H}_{2} \mathrm{SO}_{4}$ and roast-water leach processes, Geosound, 24, 141-150, 1994 (in Turkish). 
[11] Lee W. J., Yoon S. J., Chon C. M., Heo C. H., Lee G. J., Lee B. H, Cicek M., Lithium extraction from smectitic clay occurring in lithium-bearing boron deposits in Turkey, J. Miner. Soc. Korea, 29, 167-177, 2016 (in Korean).

[12] Baydır A. T., Erdoğan Y., Dissolution of the rubidium from Eti Mine Kırka Boron Management waste, AKU-J. Sci. Eng., 13, 025702, 2013 (in Turkish).

[13] Gündoğdu M. N., Yılmaz O., Methods of clay mineralogy, Proc. $1^{\text {st }}$ Nat. Clay Symp., Adana-Turkey, 319-330, 1984 (in Turkish).

[14] Komadel P., Madejová J., Janek M., Gates W. P., Kirkpatrick R. J., Stucki J. W., Dissolution of hectorite in inorganic acids, Clays Clay Miner., 44, 228-236, 1996.

[15] Steudel A., Batenburg L. F., Fischer H. R., Weidler P. G., Emmerich K., Alteration of swelling clay minerals by acid activation, Appl. Clay Sci., 44, 105-115, 2009.

[16] Van Rompaey K., Van Ranst E., De Coninck F., Vindevogel N., Dissolution characteristics of hectorite in inorganic acids, Appl. Clay Sci., 21, 241-256, 2002.
[17] Madejová J., Bujdák J., Janek M., Komadel P., Comparative FT-IR study of structural modifications during acid treatment of dioctahedral smectites and hectorite, Spectrochim. Acta, Part A, 54, 1397-1406, 1998.

[18] Grim, R. E., Clay Mineralogy, $2^{\text {nd }}$ Edition, McGraw-Hill, New York, A.B.D., 1968.

[19] Guggenheim S., Van Groos A. F. K., Baseline studies of the clay minerals society source clays: Thermal analysis, Clays Clay Miner., 49, 433-443, 2001.

[20] Yalçın S., Özbelge Ö., Acid activation of bentonite, Proc. $2^{\text {nd }}$ Nat. Clay Symp., Ankara-Turkey, 229-250, 1985 (in Turkish).

[21] Ehsani İ., Turianicová E., Baláž M., Obut A., Effects of sulphuric acid dissolution on the physical and chemical properties of a natural and a heated vermiculite, Acta Montan. Slovaca, 20, 110-115, 2015. 